\title{
Manganese Fractionation in Soils after Application of Municipal Solid Wastes Compost in Two Consecutive Years
}

\author{
Molod Samiei and Abdolamir Bostani \\ Department of Soil Science, Shahed University, Tehran, Iran \\ Correspondence should be addressed to Abdolamir Bostani; bostani@shahed.ac.ir
}

Received 15 May 2016; Revised 5 August 2016; Accepted 23 August 2016

Academic Editor: Marco Trevisan

Copyright (C) 2016 M. Samiei and A. Bostani. This is an open access article distributed under the Creative Commons Attribution License, which permits unrestricted use, distribution, and reproduction in any medium, provided the original work is properly cited.

In order to study the effect of Tehran municipal solid wastes compost on manganese accumulation in soil and to determine its concentration in any readily available plant forms (exchangeable and carbonates-bonded), Mn-oxides bonded fraction, organic matter bonded fraction, and residual fraction in a calcareous soil, a factorial experiment based on completely randomized block design (RCBD) was conducted in research field of Shahed university at different levels of municipal solid wastes compost $(0,15,30$, and 60 ton/ha) as first factor and application times (one- or two-year compost application) as second factor in three replications. Results showed that, by increasing compost level, total Mn concentration, DTPA-extractable concentration, and amounts existing in all five fractions were increased, so lowest and highest amounts of Mn were observed in control and 60 ton/ha compost application. Based on results from $\mathrm{Mn}$ fractionation using Tessier consecutive extraction method, Mn fractions in all samples were in the following order: residual $>$ Fe-Mn oxides $>$ carbonates-bonded $>$ organic matter-bonded $\gg$ exchangeable fractions in which residual fraction (RE) at first and second year was dominant rather than other fractions by 34.28-43.04 and 34.28-49.48 percent, respectively. Mn concentration in Fe-Mn oxides-bonded fraction at both years was considerable. Mn amounts in Fe-Mn oxidesbonded, application times were decreased.

\section{Introduction}

The importance of microelements for plants has already been well documented in the literature. Manganese is an essential micronutrient for all organisms, playing an important role in tissue and bone formation, in reproductive functions, and in carbohydrate and lipid metabolisms and is an important cofactor in numerous enzymes [1], but at higher levels it can be toxic. In man, chronic manganese poisoning affects the central nervous system, with symptoms resembling those of Parkinson's disease. Manganese toxicity is a serious constraint to crop cultivation since manganese is taken-up by plants and can easily be passed into the food chain $[2,3]$. Therefore, the determination of manganese in several matrices samples is very important for some areas, such as environmental chemistry and food control [4]. High manganese content hinders the uptake of calcium and magnesium. In turn, a deficiency of manganese is most often found in soils that are saline and alkaline, calcareous, or peaty [5].
Physiochemical forms of nutrients among soil components determine nutrients mobility and transferring and consequently their availability. By considering the different forms of heavy metals in soil and their changes, we could become aware of nutrients status and eventually we can plan for decrease of their absorption by plant and consequently preventing their contaminant effects by reducing transfer of these nutrients to food chain and water resources [6]. According to recent definition of international union of pure and applied chemistry (IUPAC), a practice which is widely used for recognizing nutrients distribution in solid phase is known as fractionation which is a sequential application of a chemical extractor collection for consecutive and selective solubility of chemical forms of a nutrient which was thought to be holder of major part of interested nutrients [7].

In order to determine plant's available form of nutrients, different extractors were used. It should be noted that initial purpose of each chemical extraction method is to evaluate the available amount of a nutrient for plants [8]. Consecutive 
extraction method was developed as common and essential for fractionation of trace and necessary elements such as cadmium, cobalt, nickel, lead, cupper, iron, and manganese in soil and deposits and divided them into five fractions including exchangeable, carbonate-, iron-manganese oxides-, organic matter-bonded, and residual fractions. Although using of this method is time consuming, it gives comprehensive information about trace elements origin, occurring way, bioavailability, mobility, and transferring to users [7].

Nadaska et al. [9] studied environmental aspects of manganese using consecutive extraction and believed that this method gave accurate information about origin, occurrence way, bioavailability, potential mobility, and metals transfer in natural environments. Mescouto et al. [10] showed that the highest concentration of iron and manganese is associated with residual fraction. Also, this study showed that, in fractions related to iron-manganese oxides, iron and manganese availability was in the range of 1265.139 to $1818.12 \mathrm{mg} / \mathrm{kg}$ and 48.51 to $83.0 \mathrm{mg} / \mathrm{kg}$, respectively.

The aim of the present research was to determine the fractionation of manganese in the soil in the conditions of two-year application of Tehran municipal solid waste compost in a calcareous soil. Our study can contribute to better understanding of the multidirectional transformation of those elements and to an evaluation of the amount of bioavailable forms.

\section{Methods and Materials}

In order to evaluate the different levels of Tehran municipal solid waste compost on manganese $(\mathrm{Mn})$ concentration and distribution in different soil fractions, an experiment was conducted in research station of agriculture faculty of Shahed University $\left(35^{\circ} 34^{\prime} \mathrm{N}\right.$ latitude and $51^{\circ} 34^{\prime} \mathrm{E}$ longitude). With regard to slow releasing of metals from municipal solid waste (MSW) compost, in addition to different compost application levels, compost application times are tested. Therefore, experiment was conducted as split plot (compost amounts in main plots and application times in secondary plots) in three replications on 2011-2012 and 2012-2013 cropping years. But considering homogenous conditions in experimental blocks and nonsignificant errors in main plots, traits were analyzed as factorial based on completely randomized block design (RCBD). Experimental factors including four levels of MSW application $(0,15,30$, and 60 ton/ha) were considered as first factor and compost application times (annual and biannual application) as second factor. So, main plot characterized in first year and different treatment levels were added to plots on April 2012. On April 2012, plots were divided into two parts and in one part compost was added to soil in equal amount of previous year.

After few months and reaching balance in soil, 24 soil samples were collected from surface soil of plots and after airdrying and sieving from $2 \mathrm{~mm}$ sieve, some of soil physical and chemical properties were determined, including saturation percent, saturated extract preparing, EC and $\mathrm{pH}$ [11], soil texture by hydrometer method [12], organic matter by wet oxidation [13], CEC by Bower et al. [14], and $\mathrm{CaCO}_{3}$ by pressured calcimetric method [13]. For determination of the total and available Fe and $\mathrm{Mn}$, respectively, DTPA [15] $\mathrm{HNO}_{3}$, $\mathrm{H}_{2} \mathrm{O}_{2}$ and $\mathrm{HCl}$ [16] methods were used. Mn fractionation was conducted in five fractions: exchangeable, carbonatesbonded, Fe and Mn oxides, organic matter-bonded, and residual using consecutive extraction method [17]. Finally, elements concentrations were determined by atomic absorption, Analytic Jena Contra AA300. Statistical analyses was conducted by SAS statistical software and graphs were by Excel software.

\section{Results and Discussion}

Results from determination of soil physical and chemical properties before applying treatments are presented in Table 1. After applying compost treatments it is identified that addition of compost caused the decrease in $\mathrm{pH}$ and increase in organic carbon in all levels compared to control. Studied compost by $25 \%$ organic carbon and $\mathrm{pH}$ by 2.7 is classified in standard range defined by soil and water research organization. Also, according to definition of recycling organization (2004) for compost classification in Iran, this compost due to high EC amount fell into second degree type. Total Mn in mentioned compost was determined as $426.64 \mathrm{mg} / \mathrm{kg}$.

\subsection{Effect of MSW Compost on Concentration and Distribution} of $\mathrm{Mn}$ in Soil. Table 2 shows the results on analysis of variance (ANOVA) of the effect of MSW compost on total and DTPAextractable concentration of $\mathrm{Mn}$ in soil. Also, this table shows the results for ANOVA of distribution of elements among five different fractions including: exchangeable (EX), carbonatebonded (CA) or acid-soluble, reductive Fe and Mn oxidesbonded (FM), organic matter-bonded (OM), and residual fraction (RE).

Table 3 shows mean comparisons of total and DTPAextractable concentrations and existing amounts in five different soil fractions for $\mathrm{Mn}$ at different levels of municipal solid waste compost. Results showed that, by increasing compost application percent, total and DTPA-extractable concentrations and existing amounts in five different soil fractions of $\mathrm{Mn}$ increased which the lowest and highest concentration in all studied forms observed in control and 60 ton/ha compost treatments, respectively. Osakwe [18] stated that Mn strongly attached to soil matrix. So, it is not readily available to appear in food chain. It should be noted that since total $\mathrm{Fe}$ and $\mathrm{Mn}$ concentrations in soils were measured by digestion of separate samples in related acids, total measured forms essentially were not equal to total Fe and Mn. Reyhani Tabar et al. [19] found similar results in studying the distribution of different forms of $\mathrm{Zn}$ in calcareous soils of Tehran. Mohammad and Athamneh [20] reported the increase in DTPA-extractable Fe and Mn concentration due to addition of sewage sludge compared to control. They also stated that $\mathrm{Fe}$ and $\mathrm{Mn}$ concentrations increased from 3.82 and $7.19 \mathrm{mg} / \mathrm{kg}$ in control to 13.83 and $31.63 \mathrm{mg} / \mathrm{kg}$ in the highest level of sewage sludge treatment (160 ton/ha), respectively.

Formation of stable metal complexes could decrease solubility of metal ions in soils [21]. Great amount of organic 
TABLE 1: Results of soil physical and chemical properties.

\begin{tabular}{lccccccccc}
\hline Texture & \multirow{2}{*}{ O.C $(\%)$} & \multirow{2}{*}{$\mathrm{EC}(\mathrm{dS} / \mathrm{m})$} & $\mathrm{pH}$ & $\mathrm{CCE}(\%)$ & CEC $(\mathrm{cmol} / \mathrm{kg})$ & \multicolumn{2}{c}{$\mathrm{Fe}(\mathrm{mg} / \mathrm{kg})$} & \multicolumn{2}{c}{$\mathrm{Mn}(\mathrm{mg} / \mathrm{kg})$} \\
Loam & 1.17 & 10 & 8.28 & 11.5 & 12.13 & 25712.5 & 2.78 & 1247.92 & 11.89 \\
\hline
\end{tabular}

TABLE 2: Analysis of variance and mean square values of total manganese, DTPA, and various components of municipal solid waste compost in two years.

\begin{tabular}{|c|c|c|c|c|c|c|c|c|}
\hline \multirow{2}{*}{ Sources of variation } & \multirow{2}{*}{ Degree of freedom } & \multicolumn{7}{|c|}{$\mathrm{Mn}$} \\
\hline & & EX & $\mathrm{CA}$ & FM & $\mathrm{OM}$ & $\mathrm{RE}$ & DTPA & Total \\
\hline Repeat & 2 & $0.0047^{\mathrm{ns}}$ & $23.752^{\mathrm{ns}}$ & $20.839^{\mathrm{ns}}$ & $0.063^{\text {ns }}$ & $715.367^{\text {ns }}$ & $1.845^{\mathrm{ns}}$ & $158.327^{*}$ \\
\hline MSW & 3 & $6.224^{* *}$ & $5114.509^{* *}$ & $1239.928^{* *}$ & $7.563^{* *}$ & $83627.076^{* *}$ & $18.613^{* *}$ & $34566.166^{* *}$ \\
\hline Application time & 1 & $0.484^{* *}$ & $338.701^{*}$ & $606.417^{* *}$ & $12.499^{* *}$ & $54102.51^{* *}$ & $37.697^{* *}$ & $4686.376^{* *}$ \\
\hline Time $\times$ MSW & 3 & $0.077^{* *}$ & $144.723^{*}$ & $85.137^{*}$ & $1.769^{* *}$ & $6955.364^{*}$ & $4.308^{\mathrm{ns}}$ & $1130.339^{* *}$ \\
\hline Error & 14 & 0.00465 & 41.417 & 17.148 & 0.065 & 360.789 & 1.609 & 38.9 \\
\hline Coefficient of variation & & 1.575 & 2.805 & 1.105 & 4.258 & 8.757 & 8.77 & 0.47 \\
\hline
\end{tabular}

$*, * *$, and $\mathrm{ns}$, respectively, mean significant at $5 \%$, significant at $1 \%$, and nonsignificant.

TABLE 3: Mean comparison of total and DTPA-extractable concentrations and existing amounts in 5 different soil fractions for Mn, respectively, at different levels of MSW.

\begin{tabular}{|c|c|c|c|c|c|c|c|}
\hline MSW & & & & $\mathrm{Mn}$ & & & \\
\hline $\mathrm{Tha}^{-1}$ & EX & $\mathrm{CA}$ & FM & $\begin{array}{c}\mathrm{OM} \\
\left(\mathrm{mg} \mathrm{kg}^{-1}\right)\end{array}$ & $\mathrm{RE}$ & DTPA & Total \\
\hline Control & $3.156^{\mathrm{d}}$ & $192.64^{\mathrm{d}}$ & $356.347^{\mathrm{d}}$ & $4.466^{\mathrm{d}}$ & $290.42^{c}$ & $11.889^{\mathrm{b}}$ & $1247.917^{\mathrm{d}}$ \\
\hline 15 & $3.871^{c}$ & $220.827^{\mathrm{c}}$ & $372.06^{\mathrm{c}}$ & $5.945^{\mathrm{c}}$ & $388.83^{b}$ & $14.802^{\mathrm{a}}$ & $1288.458^{c}$ \\
\hline 30 & $4.825^{\mathrm{b}}$ & $246.453^{\mathrm{b}}$ & $378.833^{\mathrm{b}}$ & $6.493^{\mathrm{b}}$ & $431.04^{\mathrm{b}}$ & $15.269^{\mathrm{a}}$ & $1324.375^{\mathrm{b}}$ \\
\hline 60 & $5.461^{\mathrm{a}}$ & $258.413^{\mathrm{a}}$ & $390.8^{\mathrm{a}}$ & $7.088^{\mathrm{a}}$ & $574.71^{\mathrm{a}}$ & $15.847^{\mathrm{a}}$ & $1425.272^{\mathrm{a}}$ \\
\hline
\end{tabular}

Similar letters in each column show nonsignificant difference at $5 \%$ probability level according to Duncan's multiple range test.

matter, its oxidation and destruction, and neutral $\mathrm{pH}$ in compost results in increasing micronutrients availability such as $\mathrm{Fe}, \mathrm{Mn}, \mathrm{Zn}$, and $\mathrm{Cu}$. The highest metal concentration was observed in the greatest compost treatments [22]. The highest concentrations of carbonates-bonded $\mathrm{Mn}$ were observed in plots in which 60 ton/ha compost was applied. This possibly is due to reaction of micronutrients with $\mathrm{CO}_{2}$ resulting from increasing in microbial activity due to higher amounts of compost application [21].

Table 4 shows the results of mean comparison of the effect of municipal solid wastes compost application times on $\mathrm{Mn}$ concentration. Based on these results, it is recognized that addition of 2 times municipal solid wastes compost over 2 years to soil significantly increased total and DTPA-extractable concentrations in all fractions except for carbonates-bonded fraction compared to one-time application. Total, DTPA-extractable, exchangeable, reductive, oxidative, and residual concentrations of $\mathrm{Mn}$ in second year compared to first year by $2.13,18.99,6.78,2.73,27.36$, and 25.4 percent, respectively. It should be noted that carbonatesbonded fraction concentration in $\mathrm{Mn}$ at two-year compost application decreased about 3.21 percent, compared to oneyear application. Sorrenti et al. [23] in the study of comparing the soil application of iron chelate and municipal solid wastes compost on nutrition status management of pear trees grown on calcareous soil showed that annual application of municipal solid wastes compost is effective in improving iron nutrition status of pear and has negative impact on availability of cations such as $\mathrm{Mn}, \mathrm{K}$, and $\mathrm{Cu}$ for plant absorption. So, compost could serve as an inexpensive and valuable strategy for improving productivity of fruit trees or orchards which has environmental and cropping advantages.

3.2. Soil Mn Fractionation. In the present study, consecutive extraction method, as described by Tessier et al. [17], was used for $\mathrm{Mn}$ fractionation. As mentioned earlier, in Tessier method total metal concentration could be divided into five fractions including exchangeable (EX), carbonate-bonded (CA), iron and manganese oxides-bonded (FM), organic matter bonded $(\mathrm{OM})$, and residual fractions (RE). Consecutive extraction method is useful for indirect evaluation of potential mobility and availability of metals for plants in soil. Assuming that availability is related to solubility, it can be concluded that metal availability decreased in following order: dissolved + exchangeable $>$ carbonate $>\mathrm{Fe}$ - and $\mathrm{Mn}$ - oxides $>$ residual. 
TABLE 4: Mean comparison of total and DTPA-extractable concentrations and existing amounts in 5 different soil fractions for Mn, respectively, at application times.

\begin{tabular}{lcccccc}
\hline $\begin{array}{l}\text { Application times } \\
\text { Tha }^{-1}\end{array}$ & EX & CA & FM & $\begin{array}{c}\text { Mn } \\
\text { OM } \\
\left(\mathrm{mg} \mathrm{kg}^{-1}\right)\end{array}$ & RE & DTPA \\
\hline One time & $4.186^{\mathrm{b}}$ & $233.34^{\mathrm{a}}$ & $369.483^{\mathrm{b}}$ & $5.276^{\mathrm{b}}$ & $373.77^{\mathrm{b}}$ & $13.198^{\mathrm{b}}$ \\
2 times & $4.47^{\mathrm{a}}$ & $225.827^{\mathrm{b}}$ & $379.537^{\mathrm{a}}$ & $6.72^{\mathrm{a}}$ & $468.73^{\mathrm{a}}$ & $1307.532^{\mathrm{b}}$ \\
\hline
\end{tabular}

Similar letters in each column show nonsignificant difference at $5 \%$ probability level according to Duncan's multiple range test.

The above order just provides qualitative information about nutrients availability for plants [24].

Table 2 shows the significant effect of different compost levels and their application times on total and DTPAextractable Mn concentrations $(P<0.01)$. In spite of significant differences of interactions of compost and application times on total Mn concentration $(P<0.01)$, the effect of this factor on DTPA-extractable Mn concentration was not significant. The effect of compost levels for all fractions $(P<0.01)$ and the effect of application times on all fractions except for carbonates-bonded fraction $(P<0.05)$ and also the interaction of compost level and application times on exchangeable and organic matter bonded fraction $(P<0.01)$ and in carbonates-bonded, Fe- and Mn-oxides, and residual fraction $(P<0.05)$ were significant (Table 2$)$. Mean comparison of total Mn, exchangeable Mn, carbonatebonded, Fe and Mn oxides, and organic matter bonded was significant in all treatments (Table 3). Mn concentrations in various soil fractions in all samples have similar trends and could be presented as follows:

$$
\mathrm{RE}>\mathrm{FM}>\mathrm{CA} \gg \mathrm{OM}>\mathrm{EX}
$$

Residual fraction (RE) in first and second year was dominant rather than other fractions in 34.28-43.04 and 34.28-49.48 percent, respectively.

$\mathrm{Fe}$ and $\mathrm{Mn}$ oxides fraction (FM) at both years was considerable, so after one year compost application changed from 42.07 percent in control treatment to 33.46 percent in 60 ton/ha compost. These amounts for second year of compost application reached 29.98 percent in 60 ton/ha treatment. As realized, Mn amounts in reductive fraction, after increasing compost levels and compost application times, were decreased. Exchangeable fraction's (EX) proportion at first year for control, 15,30 , and 60 ton/ha was $0.37,0.38,0.45$, and 0.46 percent of total extracted fractions and for second year in all treatments was very low because of higher increase in proportion of other fractions.

Proportion of carbonates-bonded fraction (CA) was considerable for $\mathrm{Mn}$. Its proportion from total $\mathrm{Mn}$ for compost treatments by $0,15,30$, and 60 ton/ha at first year were 22.74 , $24.53,24.99$, and 22.47 percent and at second year were 22.74 , $20.21,21.40$, and 19.52 percent. Mn proportion organic matter bonded fraction $(\mathrm{OM})$ at one-year application was 0.49 to 0.55 and at two-year compost application was 0.52 to 0.69 percent.

Ghaffari Nejad and Karimian [25] by determination of chemical forms of $\mathrm{Mn}$ and their relation with plant response at calcareous soils of Fars province, Iran, stated that greatest plant available $\mathrm{Mn}$ had the following order: carbonatebonded, organic matter-bonded, and dissolved + exchangeable forms. Wang and Liu [26] reported that Mn concentration in Fe and Mn oxides fraction was more than carbonatebonded and then exchangeable fraction. In a calcareous soil, concentration of metals in carbonate-bonded fraction followed the following order: cadmium « copper-lead < zinc $<$ manganese [27]. So, with regard to great affinity of $\mathrm{Mn}$ to binding with carbonates, higher concentration of $\mathrm{Mn}$ compared to Fe in the same fraction and also compared to $\mathrm{Mn}$ presented in organic matter bonded fraction is expectable. Also, Fe and Mn oxides-bonded concentration of Mn compared to other fractions except for residual fraction was higher which is consistent with Ajayi et al's [27] findings showing the compatibility of studied metals in Fe and Mn oxides fraction with the following order: $\mathrm{Cd} \ll \mathrm{Cu}<\mathrm{Pb}<$ $\mathrm{Mn}$. Therefore, this fraction by stable and strong behavior was accounted as most effective phase for binding to heavy metals in soil and important absorbent for them. Based on Adriano report's [28] with regard to attitude of heavy metals to formation of insoluble organic complexes in the order of $\mathrm{Zn}^{2+}<\mathrm{Mn}^{2+}<\mathrm{Co}^{2+}<\mathrm{Ni}^{2+}<\mathrm{Pb}^{2+}<\mathrm{Fe}^{2+}<\mathrm{Cd}^{2+}<\mathrm{Cu}^{2+}$, we could explain considerably lower concentration of organic matter-bonded Mn compared to other fractions.

Results from interactions of different levels of municipal solid wastes compost and application times on Mn concentration at different fractions are shown in Figure 1.

Mn concentration in exchangeable phase (instable position) increased from $3.156 \mathrm{mg} / \mathrm{kg}$ soil at control treatment to $5.563 \mathrm{mg} / \mathrm{kg}$ in two-year application of $60 \mathrm{ton} / \mathrm{ha}$ compost. Oxidation and reduction of soil Mn could occur simultaneously (but independently) at close positions [29] which could be determinative in increase or decrease of $\mathrm{Mn}$ availability. Oxidative-reductive status of Fe rather than Mn usually is reversible. So, different reactions of $\mathrm{Mn}$ to oxidative-reductive changes are slower [30]. Also, results showed that exchangeable Mn content significantly increased after addition of compost as well as two-year application $(P<0.01)$.

Higher amounts of $\mathrm{Mn}$ in other soil fractions (stable positions) are related to residual fraction and the lowest amount is related to organic matter-bonded fraction. Mn existed in reductive, oxidative, and residual fractions significantly increased by increasing compost application at one-year as well as increasing application times from one-year to twoyear. Mn content increasing could be due to the effect of time on conversion of soil $\mathrm{Mn}$ to more stable form. Also, results 

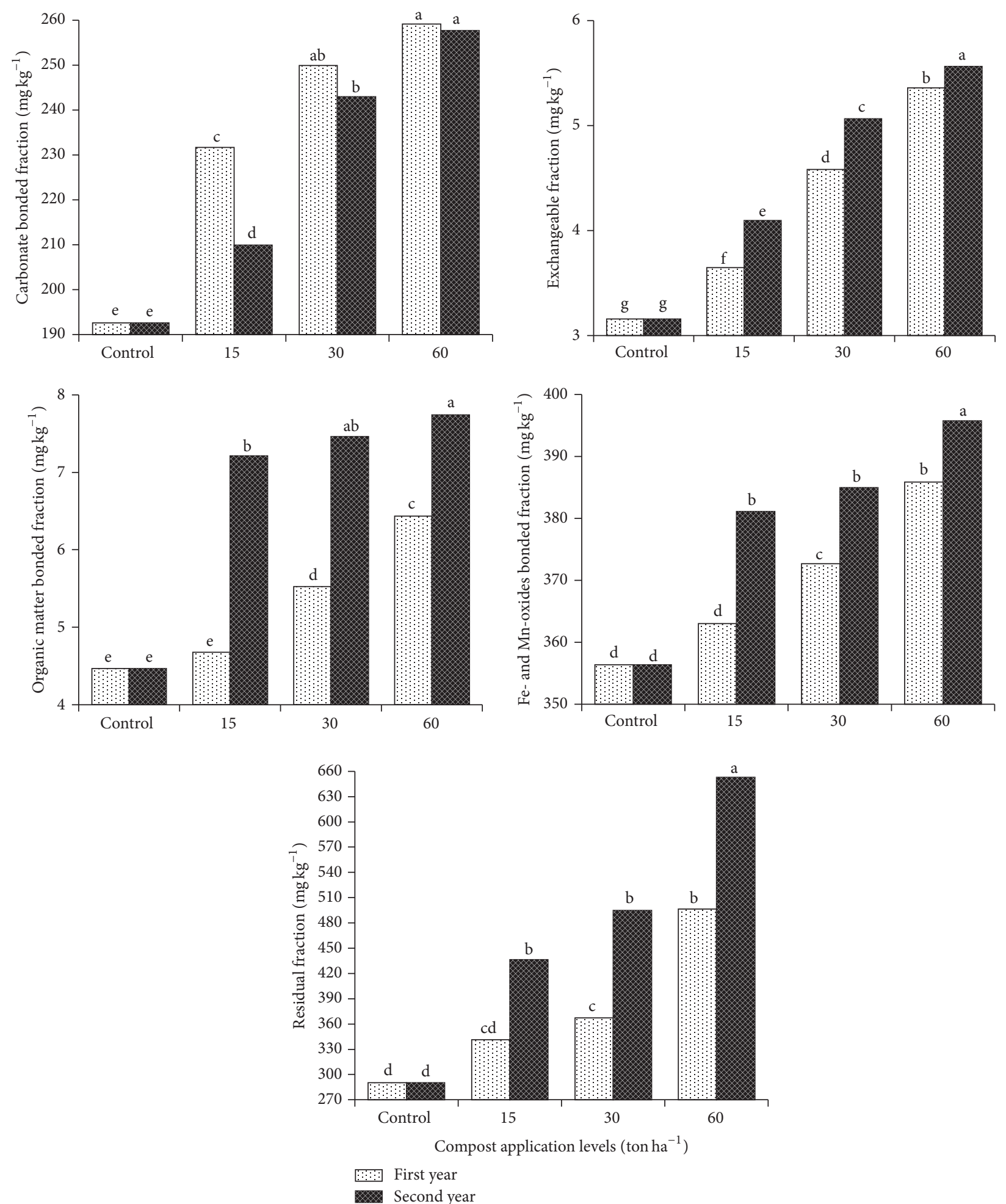

FIGURE 1: Effect of interactions between compost application levels and compost application times over two consecutive years on various components of manganese concentration in soil. Letters a-g indicate significant difference between means according to Duncan multiple range test at $5 \%$ probability level. 

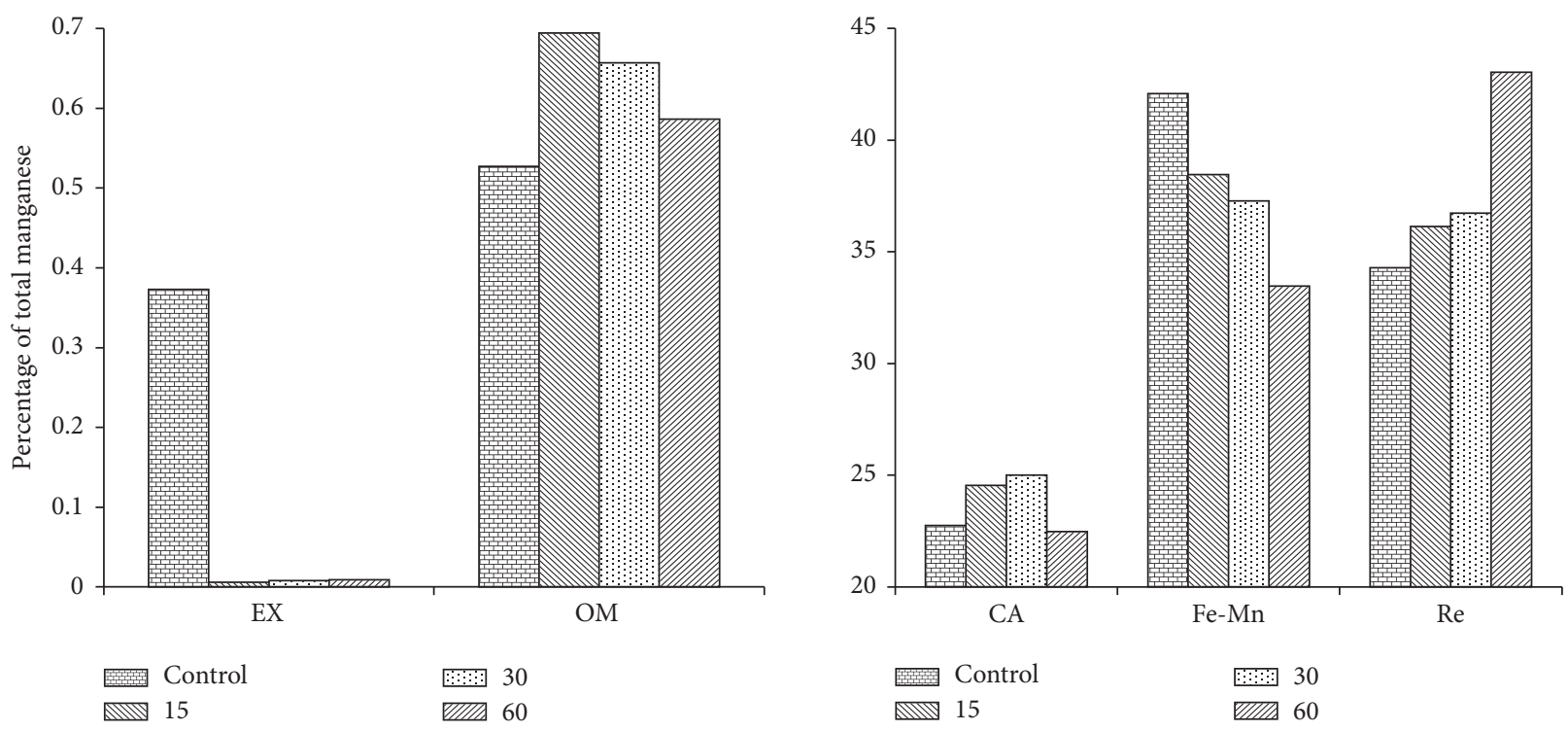

(a)
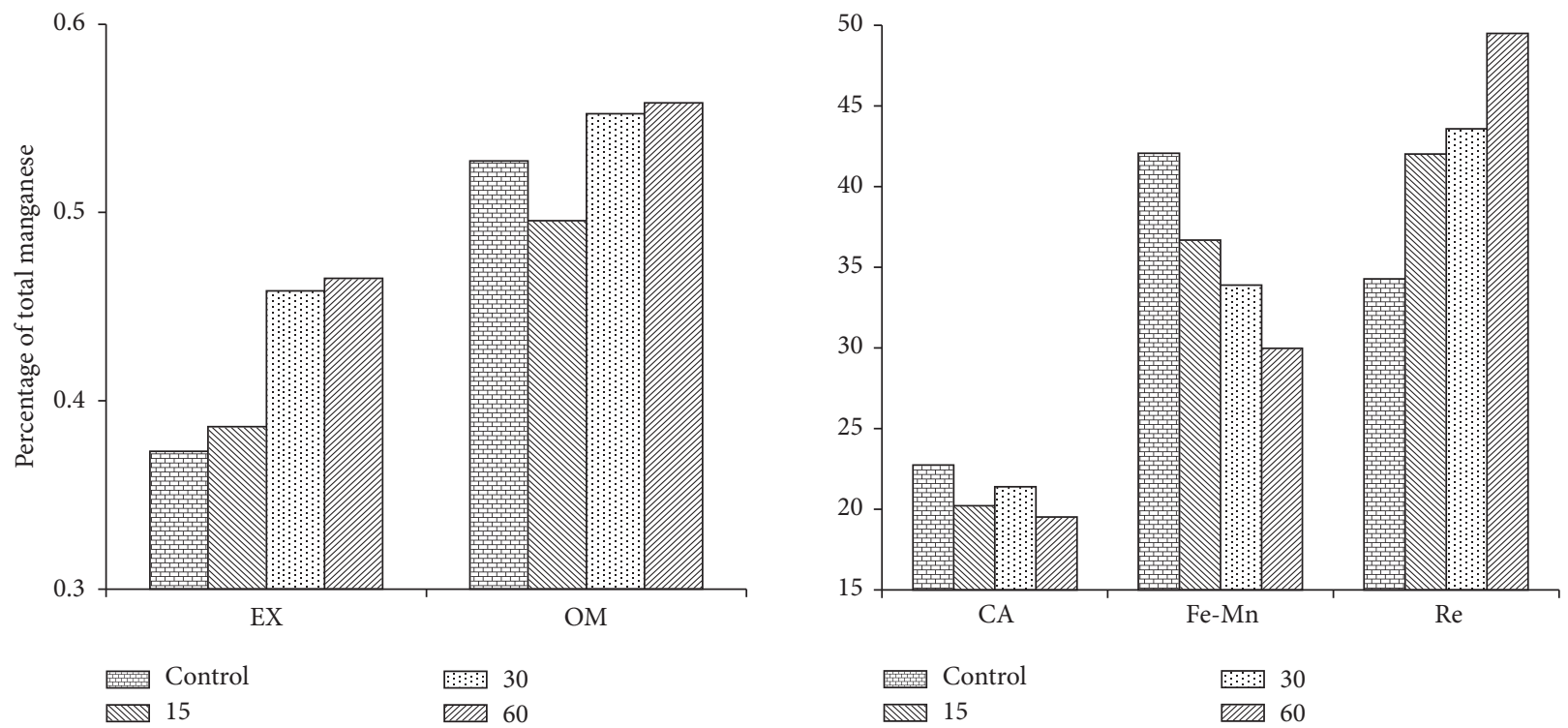

(b)

FIGURE 2: Fractionation of manganese after one-year (a) and two-year (b) application of municipal solid waste compost.

showed that almost in all studied samples, carbonate-bonded fraction after residual and Fe and Mn oxides has the highest Mn amounts. Mn amount in this fraction after addition of compost levels, separately in each year, significantly increased $(P<0.01)$, while Mn amount in all treatments from one-time application to two-time significantly decreased $(P<0.05)$. So carbonates-bonded $\mathrm{Mn}$ in 15,30, and 60 ton/ha at second year compared to first year significantly decreased by 10.33 , 2.85 , and 0.55 percent, respectively.

Organic matter-bonded fraction was followed by residual, Fe-, and Mn-oxides and carbonates-bonded fractions. Changes of this fraction are in the range between $4.46 \mathrm{mg} / \mathrm{kg}$ in control and $7.74 \mathrm{mg} / \mathrm{kg}$ in two-year 60 ton/ha compost application which is lower than carbonate-bonded, Fe and Mn oxides, and residual fractions but higher than that for exchangeable fraction. $\mathrm{Mn}$ in the form of organic matter bonded form increased by addition of compost from 0 to 15 , 30 , and 60 ton/ha at first and second years by 4.7, 23.76, 44.17, and 61.65, 67.26, and 73.54 percent (Figure 2). Mescouto et al. [10] studied the distribution and availability of nutrients like $\mathrm{Cu}, \mathrm{Fe}, \mathrm{Mn}$, and $\mathrm{Zn}$ according to Tessier consecutive extraction method and found that highest concentrations of nutrients are associated with residual fraction. Zheljazkov and Warman [31] studied the fractionation of $\mathrm{Cu}, \mathrm{Mn}$, and $\mathrm{Zn}$ in soils after application of two compost types, one resulting from municipal solid waste for sugar beet and basil and the 
TABLE 5: Correlation coefficient between soil physical and chemical properties and total and available forms of Mn.

\begin{tabular}{|c|c|c|c|c|c|}
\hline \multirow{2}{*}{ Mn Forms } & EC & $\mathrm{pH}$ & OC & CCE & CEC \\
\hline & $\mathrm{ds} \mathrm{m}^{-1}$ & - & \multicolumn{2}{|c|}{$\%$} & $\mathrm{cmol}_{\mathrm{c}} \mathrm{kg}^{-1}$ \\
\hline EX & $0.98^{* *}$ & $-0.88^{* *}$ & $0.93^{* *}$ & $-0.36^{\mathrm{ns}}$ & $0.98^{* *}$ \\
\hline $\mathrm{CA}$ & $0.90^{* *}$ & $-0.83^{* *}$ & $0.78^{* *}$ & $-0.50^{*}$ & $0.86^{* *}$ \\
\hline FM & $0.91^{* *}$ & $-0.89^{* *}$ & $0.95^{* *}$ & $-0.40^{*}$ & $0.93^{* *}$ \\
\hline $\mathrm{OM}$ & $0.81^{* *}$ & $-0.84^{* *}$ & $0.92^{* *}$ & $-0.33^{\mathrm{ns}}$ & $0.82^{* *}$ \\
\hline $\mathrm{RE}$ & $0.89^{* *}$ & $-0.83^{* *}$ & $0.94^{* *}$ & $-0.39^{\text {ns }}$ & $0.90^{* *}$ \\
\hline DTPA & $0.91^{* *}$ & $-0.99^{* *}$ & $0.93^{* *}$ & $-0.60^{*}$ & $0.88^{* *}$ \\
\hline Total & $0.94^{* *}$ & $-0.80^{* *}$ & $0.94^{* *}$ & $-0.38^{\mathrm{ns}}$ & $0.95^{* *}$ \\
\hline
\end{tabular}

$*, * *$, and $\mathrm{ns}$, respectively, mean significant at $5 \%$, significant at $1 \%$, and nonsignificant.

other one a compost fertilizer containing great amounts of $\mathrm{Cu}$ for tomato and mint and found that using of municipal solid wastes compost increased $\mathrm{Cu}$ and $\mathrm{Zn}$ concentration in all fractions and $\mathrm{Mn}$ concentration in carbonates-, FeMn oxides-, and organic matter-bonded fractions, while resulting in decrease in exchangeable fraction. Achiba et al. [32] studied the heavy metals distribution among different fractions of treated and untreated soils and showed that, after residual fraction, Fe-Mn oxides fractions are dominant. Organic matter bonded fraction of $\mathrm{Cu}$ increased by increasing compost application possibly due to formation of organic complexes. Based on results of Osakwe [18] for chemical and mobile species of $\mathrm{Fe}, \mathrm{Co}, \mathrm{Ni}$, and $\mathrm{Mn}$ using Tessier consecutive extraction method [17] in soils around automobile wastes landfill in Nigeria, it was determined that great parts of $\mathrm{Fe}$ and $\mathrm{Mn}$ are associated with residual fraction.

3.3. Correlation between Different Forms of $M n$ and Soil Physical and Chemical Properties. Results from correlation between soil physical and chemical properties and total and available forms as well as exchangeable, carbonates-bonded, Fe-Mn oxides-bonded, organic matter bonded, and residual fractions of $\mathrm{Mn}$ are shown in Table 5. There was significant and negative correlation between calcium carbonate equal (CCE) content and carbonate-bonded Mn fraction (-0.50). There was significant and strong correlation between soil organic matter and organic matter bonded fraction of $\mathrm{Mn}$ (0.92). Soil $\mathrm{pH}$ has significant and negative correlation with all forms of Mn. In these soils, $\mathrm{pH}$ is in the neutral and alkaline range which caused more absorption of $\mathrm{Mn}$ and less solubility of these nutrients; hence, exchangeable $\mathrm{Mn}$ in these soils was very low. Results from linear correlation coefficient showed that, by increasing soil cation exchange capacity and organic matter, concentration of various fractions of $\mathrm{Mn}$ would increase and by decreasing soil $\mathrm{pH}$ and carbonates, $\mathrm{Mn}$ absorption by different soil phases was lower and its solubility will increase.

Ghaffari Nejad and Karimian [25] studied the relations between soil physical and chemical properties and chemical forms of $\mathrm{Mn}$ and found the correlation between soil CCE and carbonate-bonded Mn. Moharrami and Jalali [6] studied the competitive absorption of heavy metals and showed that soil
$\mathrm{pH}$, clay, and silt content were effective on CEC and CCE was effective on Cd and Mn and only CCE influenced Mn.

\section{Conclusion}

Results showed that, by increasing compost level, total concentration of $\mathrm{Mn}$ and DTPA-extractable concentrations in all fractions increased, so that lowest and highest amounts of $\mathrm{Mn}$ were observed in control and 60 ton/ha compost application.

Mn fractionation showed that the highest amount was associated with residual fraction and the lowest amount was for organic matter bonded fraction. Mn existed in Fe-Mn oxides and organic matter-bonded and residual fractions increased by increasing compost application amount at firstyear and two-year compost application further increased $\mathrm{Mn}$ content in all fractions. This represents the effect of time on conversion of more amounts of soil $\mathrm{Mn}$ to more stable forms. Also, results showed that, almost in all studied samples, carbonates-bonded fraction after residual and $\mathrm{Fe}-\mathrm{Mn}$ oxides fraction had the highest Mn amounts. Exchangeable fraction (EX) contribution at first year for $0,15,30$, and 60 ton compost/ha was $0.37,0.38,0.45$, and 0.46 percent from the sum of all extracted fractions and in second year very low amounts were obtained, but exchangeable Mn amount after addition of compost and increase in application time to two years significantly increased.

\section{Competing Interests}

The authors declare that they have no competing interests.

\section{Acknowledgments}

The authors gratefully acknowledge the support of Iran National Science Foundation (INSF) for conducting the present study.

\section{References}

[1] A. P. dos Anjos, L. Cornejo-Ponce, S. Cadore, and N. Baccan, "Determination of manganese by flame atomic absorption spectrometry after its adsorption onto naphthalene modified 
with 1-(2-pyridylazo)-2-naphthol (PAN)," Talanta, vol. 71, no. 3, pp. 1252-1256, 2007.

[2] C. E. Banks, J. Kruusma, R. R. Moore et al., "Manganese detection in marine sediments: anodic vs. cathodic stripping voltammetry," Talanta, vol. 65, no. 2, pp. 423-429, 2005.

[3] G. F. Pearson and G. M. Greenway, "Recent developments in manganese speciation," TrAC-Trends in Analytical Chemistry, vol. 24, no. 9, pp. 803-809, 2005.

[4] V. A. Lemos, P. X. Baliza, A. L. de Carvalho, R. V. Oliveira, L. S. G. Teixeira, and M. A. Bezerra, "Development of a new sequential injection in-line cloud point extraction system for flame atomic absorption spectrometric determination of manganese in food samples," Talanta, vol. 77, no. 1, pp. 388-393, 2008.

[5] M. B. McBride, Environmental Chemistry of Soils, Oxford University Press, 1994.

[6] S. Moharrami and M. Jalali, "Effect of cations Ca, NH4, Na, K on distribution of species heavy metals in contaminated soils," in Proceedings of the Soil Conference, Environment and Sustainable Development, 2006.

[7] Ch. Gleyzes, S. Tellier, and M. Astruc, "Fractionation studies of trace elements in contaminated soils and sediments: a review of sequential extraction procedures," TrAC-Trends in Analytical Chemistry, vol. 21, no. 6-7, pp. 451-467, 2002.

[8] M. Zarrabi and M. Jalali, "Comparison of several extractor to extract available Potassium for wheat in some soils of Hamedan," Iranian Journal of Soil and Water Research, vol. 2, no. 40, pp. 155-149, 2009.

[9] G. Nadaska, J. Lesny, and I. Michalik, "Environmental aspect of manganese chemistry," Chemistry, HEJ: ENV-100702-A, 2010.

[10] C. S. T. Mescouto, V. P. Lemos, H. A. Dantas Filho, M. L. da Costa, D. C. Kern, and K. G. Fernandes, "Distribution and availability of copper, iron, manganese and zinc in the archaeological black earth profile from the amazon region," Journal of the Brazilian Chemical Society, vol. 22, pp. 1484-1492, 2011.

[11] J. D. Rhoades, "Soluble salts," in Method of Soil Analysis. Part 2. Chemical and Microbiological Properties, A. L. Page, Ed., Agronomy Monograph No. 9, pp. 167-179, SSSA and ASA, Madison, Wis, USA, 2nd edition, 1982.

[12] G. W. Gee and J. W. Bauder, "Particle-size analysis," in Methods of Soil Analysis. Part 1, A. Klute, Ed., pp. 383-412, ASA, SSSA, Madison, Wis, USA, 2nd edition, 1986.

[13] D. W. Nelson and L. E. Sommers, "Total carbon, organic carbon, and organic matter," in Methods of Soil Analysis. Part II, A. L. Page et al., Ed., pp. 539-579, ASA, SSSA, Madison, Wis, USA, 2nd edition, 1982.

[14] C. A. Bower, R. F. Reitemeier, and M. Fireman, "Exchangeable cation analysis of saline and alkali soils," Soil Science, vol. 73, no. 4, pp. 251-262, 1952.

[15] W. L. Lindsay and W. A. Norvell, "Development of a DTPA soil test for zinc, iron, manganese, and copper," Soil Science Society American Journal, vol. 42, no. 3, pp. 421-428, 1978.

[16] P. K. Gupta, Soil, Plant, Water, and Fertilizer Analysis, Agrobios, New Delhi, India, 2000.

[17] A. Tessier, P. G. C. Campbell, and M. Blsson, "Sequential extraction procedure for the speciation of particulate trace metals," Analytical Chemistry, vol. 51, no. 7, pp. 844-851, 1979.

[18] S. A. Osakwe, "Chemical speciation and mobility of some heavy metals in soils around automobile waste dumpsites in northern part of Niger Delta, South Central Nigeria," Journal of Applied
Sciences and Environmental Management, vol. 14, no. 4, pp. 123130, 2010.

[19] A. Reyhani Tabar, N. Karimiyan, M. Mezardelan, and M. Ghannadha, "Distribution of various forms of Zinc and communicate them with Soil characteristics of some calcareous soils of Tehran," Science and Technology of Agriculture and Natural Resources, vol. 3, pp. 125-135, 2006.

[20] M. J. Mohammad and B. M. Athamneh, "Changes in soil fertility and plant uptake of nutrients and heavy metals in response to sewage sludge application to calcareous soils," Journal of Agronomy, vol. 3, no. 3, pp. 229-236, 2004.

[21] M. Hamidpour, M. Afyuni, E. Khadivi, A. Zorpas, and V. Inglezakis, "Composted municipal waste effect on chosen properties of calcareous soil," International Agrophysics, vol. 26, no. 4, pp. 365-374, 2012.

[22] S. Roghanian, H. Mirsyedhosseini, G. H. Savaghebi, L. Halajian, M. Jamei, and H. Etesami, "Effects of Composted Municipal Waste and its leachate on some soile chemical properties and Corn plant responses," International Journal of Agriculture, vol. 2, no. 6, pp. 801-814, 2012.

[23] G. Sorrenti, M. Toselli, and B. Marangoni, "Use of compost to manage Fe nutrition of pear trees grown in calcareous soil," Scientia Horticulturae, vol. 136, pp. 87-94, 2012.

[24] F. X. Han and A. Banin, "Selective sequential dissolution techniques for trace metals in arid-zone soils: the carbonate dissolution step," Communications in Soil Science and Plant Analysis, vol. 26, no. 3-4, pp. 553-576, 1995.

[25] S. A. Ghaffari Nejad and N. Karimian, "Determination of chemical forms of manganese and their relations with soybean responses in some calcareous soils of fars province," Journal of Water and Soil Sciences, vol. 11, no. 1, pp. 125-134, 2007.

[26] J. F. Wang and Z. Liu, "Effect of nitrogen and manganese fertilizer on chemical form of manganese influvo-aquie soil," Jiangsu Journal of Agricultural Sciences, vol. 15, no. 4, pp. 223236, 1999.

[27] S. O. Ajayi, B. O. Odesanya, A. O. Avwioroko, G. S. Adebambo, and B. Okafor, "Effects of long term fertilizer use on trace metal levels of soils in a farm settlement," Agricultural Research and Development, vol. 2, no. 2, pp. 44-51, 2012.

[28] D. C. Adriano, Trace Elements in Terrestrial Environments: Biogeochemistry, Bioavailability, and Risks of Metals, Springer, New York, NY, USA, 2001.

[29] L. A. Sparrow and N. C. Uren, "Oxidation and reduction of Mn in acidic soils: effect of temperature and soil pH," Soil Biology and Biochemistry, vol. 19, no. 2, pp. 143-148, 1987.

[30] H. L. Bohn, B. L. McNeal, and G. A. Oconner, Oconner, Soil Chemistry, John Wiley \& Sons, New York, NY, USA, 2nd edition, 1985.

[31] V. D. Zheljazkov and P. R. Warman, "Phytoavailability and fractionation of copper, manganese, and zinc in soil following application of two composts to four crops," Environmental Pollution, vol. 131, no. 2, pp. 187-195, 2004.

[32] W. B. Achiba, N. Gabteni, A. Lakhdar et al., "Effects of 5-year application of municipal solid waste compost on the distribution and mobility of heavy metals in a Tunisian calcareous soil," Agriculture, Ecosystems and Environment, vol. 130, no. 3-4, pp. 156-163, 2009. 

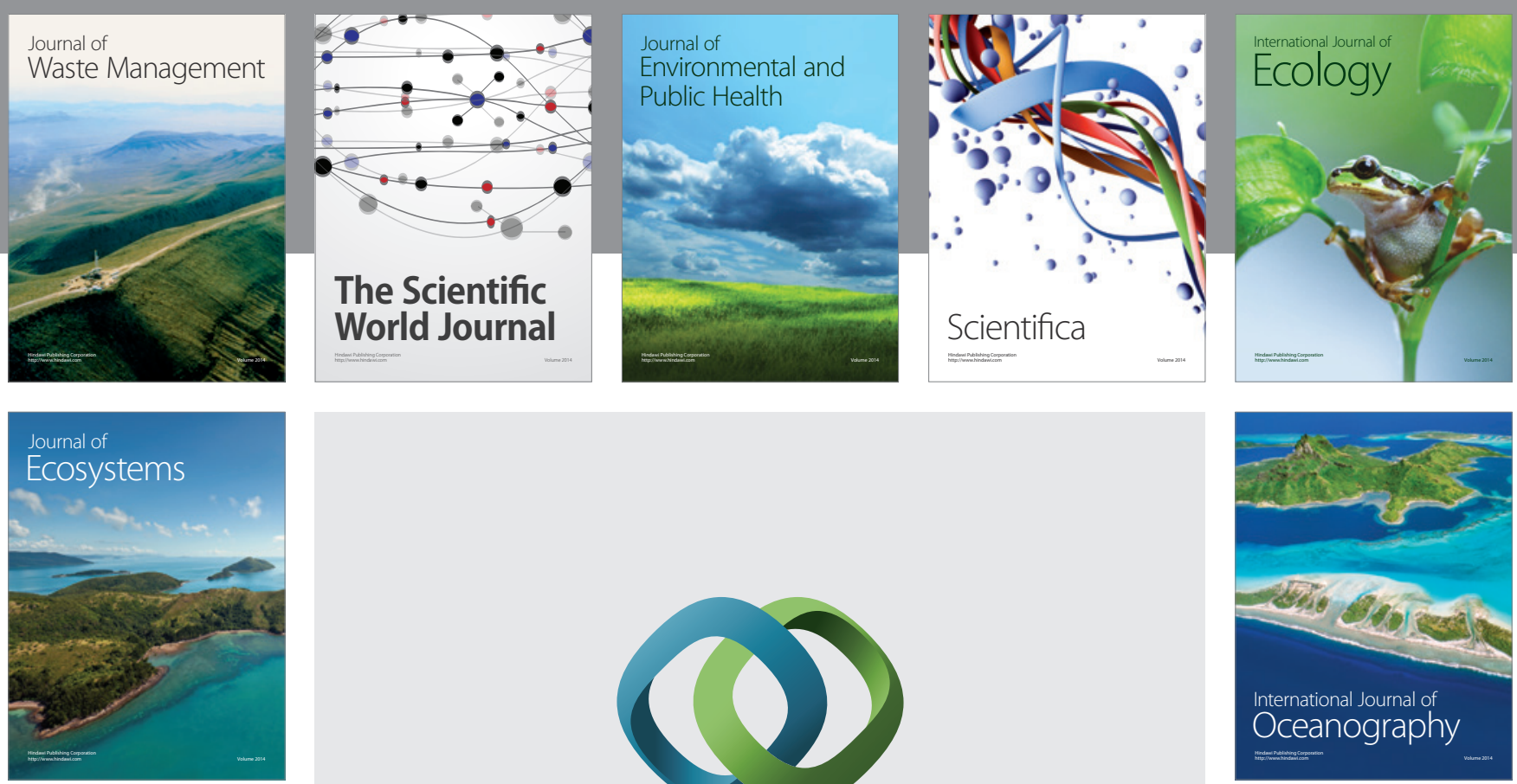

The Scientific World Journal
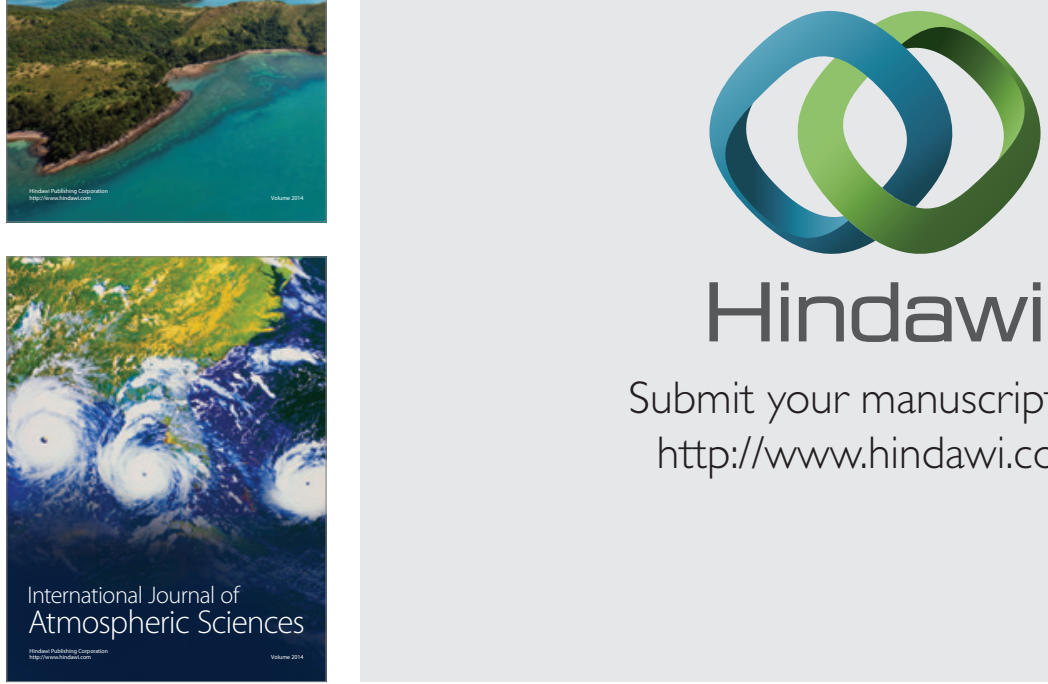

\section{Hindawi}

Submit your manuscripts at

http://www.hindawi.com
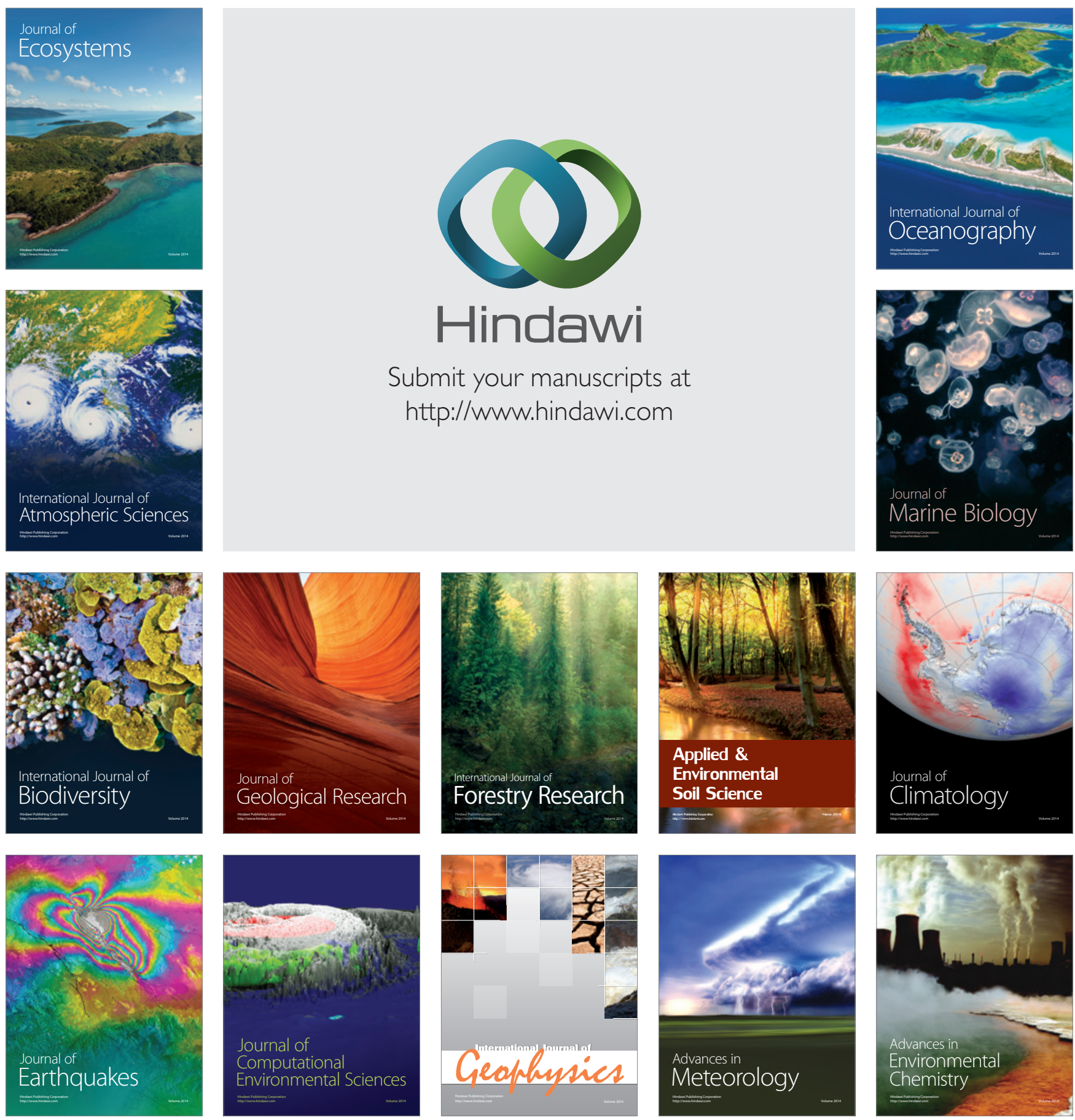